\title{
Chapter 9 \\ The Role of Higher Education in Creating Socially Responsible Innovations: A Case Study of the EIT Food RIS Consumer Engagement Labs Project
}

\author{
Krzysztof Klincewicz, Magdalena Zatorska, and Anna Wielicka-Regulska
}

\begin{abstract}
The chapter discusses the concept of socially responsible innovations and links it to the third mission of universities, understood in terms of social engagement of the higher education institutions. It presents the case study of the EIT Food RIS Consumer Engagement Labs project (funded by the European Institute of Innovation and Technology, EIT, in the framework of Regional Innovation Scheme, RIS). The project has been rolled out to 14 European countries. It serves as a successful example of universities orchestrating the process of co-creation of new products, which involves consumers and producers. The process aimed to address societal challenges and serve the needs of a vulnerable group of senior citizens by developing new food products, proposed by the elderly consumers and matching their specific needs and requirements. It looks at the project experiences through the lenses of inclusion and responsiveness, which allow the universities to combine social responsibility with commercially attractive innovations. Universities involved in the project were playing the role of "interpreters", linking companies and consumers, facilitating the creative activities and ensuring the methodological and ethical soundness of the co-creation processes.
\end{abstract}

Keywords Responsible research and innovation - Socially responsible innovations · Co-creation · University · Third mission

K. Klincewicz $(\bowtie) \cdot$ M. Zatorska

Faculty of Management, University of Warsaw, Warsaw, Poland

e-mail: kklincewicz@wz.uw.edu.pl; magdalena.zatorska@uw.edu.pl

A. Wielicka-Regulska

Faculty of Economics, Poznań University of Life Sciences, Poznań, Poland

e-mail: anna.wielicka@up.poznan.pl

C. Păunescu et al. (eds.), Social Innovation in Higher Education, Innovation,

Technology, and Knowledge Management,

https://doi.org/10.1007/978-3-030-84044-0_9 


\section{The Key Points of the Chapter Are the Following}

- Universities can actively stimulate the development of socially responsible innovations in the private sector by orchestrating co-creation processes.

- Co-creation of new products, involving consumers and producers, may address the needs of vulnerable or previously overlooked citizens.

- Universities facilitating co-creation strengthen the inclusion and responsiveness dimensions of this process, intermediating between companies and citizens.

- Through co-creation, socially responsible approaches can strengthen both the commercial and ethical aspects of product development.

- The chapter documents experiences of the EIT Food RIS Consumer Engagement Labs project, focused on development of new food products with the involvement of elderly consumers.

\section{Introduction}

The modern role of universities goes beyond teaching and research and is determined by the changing needs and expectations of the society, with scientists and university administrators reacting to various external conditions and identified societal challenges. The recognition of the economic potential of academic research has led to an increase in research commercialization activities but has also made the universities more capable of solving important social problems by leveraging the accumulated scientific knowledge. This social engagement of universities is often referred to as "the third mission". In fulfilling this mission, universities develop and implement social innovations and socially responsible innovations.

The chapter presents the possible role of universities in promoting socially responsible innovations. It discusses the third mission of universities, outlining differences between their commercial and societal orientation. It further introduces the notion of socially responsible innovations, differentiates it from social innovations and puts in a broader context of literature on responsible research and innovation.

The discussion is illustrated by a case study of the EIT Food RIS Consumer Engagement Labs project (www.timo.wz.uw.edu.pl/cel), as an example of good practices in implementing responsible research and innovations, or socially responsible innovations. The project involved a specific category of societal interactions, namely the co-creation of new products by consumers and producers. In 14 European countries, universities participating in the project were working together with seniors and food sector companies, uncovering the needs of elderly consumers, designing new food products that satisfy their specific requirements, and supporting companies in launching them on the market. In the analysed case study, universities were acting in a new role of intermediators of a dialogue between consumers and producers. The project targeted a vulnerable group of citizens (seniors), ensuring their recognition by food producers regardless of the limited profitability of this consumer segment. 
As the chapter will demonstrate, universities have the potential to catalyse innovations in the private sector. This could happen by support for the co-creation processes and for the development of products and services, proposed as outcomes of the co-creation, based on scientific knowledge, good practices and specialist methodologies. The example of the EIT Food RIS Consumer Engagement Labs project highlights the unique position of universities as supporters of the private sector endeavours, adding credibility and pro-social impact, ensuring their methodological and ethical soundness and encouraging companies to pursue socially responsible strategies.

The chapter is empirically founded, going beyond the present understanding of the third mission and social impacts that could be spurred by universities. It will discuss the opportunities for deeper involvement of universities with external stakeholders, presenting a specific scenario of new product co-creation as an example of a desirable intervention aimed at addressing important societal challenges by higher education.

\section{The Third Mission of Universities}

The role of higher education institutions (HEIs) evolved from "ivory towers", purely interested in the pursuit of knowledge and free from external influences (Ocean et al., 2020) towards becoming active players in regional innovation ecosystems. Universities are nowadays regarded as key contributors to the economic prosperity of the region through knowledge creation and dissemination (Fukugawa, 2017), and many of them also try to address societal and environmental problems, performing important social functions (Secundo et al., 2017). In the second half of the twentieth century, the latter role was described as the "third mission" (Etzkowitz, 1983; Etzkowitz, 2013), which complements academic research and teaching, placing the university at the service of society (Gimenez \& Bonacelli, 2019, p. 12).

Historically, the emergence of the HEIs' third mission could be traced back to the reliance of the leading US universities such as MIT, Stanford or Harvard on the private sources of funding, making them naturally more attentive to the needs of external non-academic stakeholders. This has increased the importance of knowledge transfer by patenting, licensing, creation of spin-off companies and investments in start-ups (Etzkowitz et al., 1998), and strengthened interactions between universities, industry and other societal stakeholders (Leydesdorff \& Etzkowitz, 1998). European universities followed a similar path, extending the Humboldtian paradigm of a research university and acknowledging the societal importance of academic endeavours (Trencher et al., 2014). The concept of the third mission goes beyond the mere commercialization of research and could be understood as a process of public engagement intended to solve problems relevant to a society or a community and thereby, contribute to the increased innovativeness and social changes (SánchezBarrioluengo \& Benneworth, 2019; for other definitions of the third mission, see e.g., Papadimitriou, 2020; Rubens et al., 2017). Of particular importance is the cooperation between universities and their stakeholders (Aversano et al., 2020), aimed at "the social, cultural and economic development of communities" 
(Compagnucci \& Spigarelli, 2020, p. 6), capable of addressing specific societal challenges (Kattel \& Mazzucato, 2018). Owing to their third missions, HEIs can actively participate in the public debate and actions tackling issues of transnational importance such as climate change, ageing, digital transformation, health or economic crises (Wanzenböck et al., 2020). The civic engagement of universities (Buffel et al., 2017) drives their embeddedness in the local environment and the provision of services to the local communities.

Implementing the third mission comes at a cost. Universities establish living laboratories, science shops, policy labs, maker spaces, fab labs and open online courses. Scientists devote their time to public participation, knowledge dissemination and various communal duties. Stakeholder collaboration to jointly tackle societal problems usually requires the involvement of interdisciplinary teams over some time (Flores et al., 2007). Furthermore, the pursuit of the third mission poses the risk of diverting financial and human resources from the generation of new scientific knowledge and teaching responsibilities of the university and might not be adequately captured by the indicators typically used to evaluate academic performance (Lund, 2020).

The third mission is linked to the social responsibility of universities, frequently discussed as the responsible research and innovation (Inigo \& Blok, 2019; Carrier \& Gartzlaff, 2020), where science works for the benefits of society (Owen et al., 2012). This societal alignment of universities is not unquestionable (Ribeiro et al., 2018) and might actually clash with the neoliberal tendencies in higher education (Taylor, 2017; Torres \& Schugurensky, 2002). The challenges of the social responsibility of the higher education sector will be discussed in the following sub-chapter.

\section{Socially Responsible Innovations}

The concept of responsible innovations is interpreted as "taking care of the future through collective stewardship of science and innovation in the present" (Stilgoe et al., 2013, p. 1570), which translates into developing and diffusing innovative solutions to important societal challenges. The typical dimensions of responsible innovation encompass the anticipation of innovation consequences, reflexivity, the inclusion of stakeholders in decision-making processes and responsiveness (Stilgoe et al., 2013, pp. 1570-1573). For an extensive review of literature on responsible innovations, see Schuijff and Dijkstra (2019).

Socially responsible innovations differ from social innovations-manifestations of changes that address identified societal problems (Cajaiba-Santana, 2014), aimed at improving the welfare of individuals or communities (OECD/Eurostat, 2018, p. 252), not necessarily embodied in technologies but rather enacted through institutions, practices and social processes (Jessop et al., 2013), without material form or technological dimensions. Stakeholder collaboration is at the core of responsible research and innovation (Jarmai \& Vogel-Pöschl, 2020), driven by the responsiveness towards the society and the needs of its members (Nielsen, 2016). 
Interestingly, the voices of potential users and societal stakeholders are not always listened to by companies while developing and commercializing innovations. Corporate approaches to new products and services are often criticized for "innovation gone mad" (Laloux, 2014, p. 29), i.e., disregarding expectations of customers and instead, trying to stimulate demand for otherwise unwanted products. Sophisticated technologies gradually lose connection to the needs of actual users, as the "high tech intoxication" of companies progresses (Naisbitt, 2001, p. 12). This disconnection between users and suppliers is further exacerbated by investors, who tend to finance fashionable technological fields, not necessarily desired by average citizens (Perez, 2002). Empirical studies indicate that lack of understanding of customer needs belongs to the most common sources of innovation failures (Freeman \& Soete, 1997, p. 381). Pro-innovation bias is the erroneous assumption that all innovations are beneficial (Rogers, 1995, p. 100), even though they are not always useful. The differentiated usefulness of innovations might encompass being good for an individual user, for people surrounding the user, for the industry or for the broader society (Berkun, 2007, pp. 138-140). Innovations tend to contribute towards the rise in inequality and in socioeconomic gaps between members of societies or countries (Rogers, 1995, p. 125) that can benefit from the novelties or are barred from using them.

The increased importance of users or customers in innovation processes has an important ethical angle, strengthening the socially responsible conduct of companies. Customers are nowadays well informed and active, owing to the ubiquitous information access and frequency of communication with peers including domain experts (Prahalad \& Ramaswamy, 2006, pp. 2-6). They are capable of offering direct inputs into the design and development of new products and services, in a process described as the co-creation of value between customers and producers (Prahalad \& Ramaswamy, 2006, p. 22). The role of users in refining the functionality and usage patterns of technological artefacts was observed in the history of technologies (Bijker et al., 1989), but it could now be elevated to a new level with the explicit involvement of users in the generation of new product concepts through co-creation initiatives. Innovations may be generated by amateur users and hobbyists, including through DIY (do-it-yourself) communities formed around products, “customer hacking" (Tapscott \& Williams, 2006, pp. 128-135), or collective development efforts responding to specific needs of users, which circumvent companies or intellectual property rights (Potts, 2019, p. 156).

More structured co-creation initiatives foresee also specific roles for companies, which interact with users and jointly create innovative concepts. Co-creating users reveal product characteristics perceived by them as valuable and as Miller and Swaddling (2002) argue, such insights might even be superior to findings of traditional research techniques aimed at eliciting requirements such as individual or group interviews. Typical co-creation sessions involve "average" customers, with the composition of the panel striving for representativeness and diversity, and this differs from the lead users' workshops, focused on the most active users of a given product category (Meadows, 2002), capable of recommending specific 
improvements based on their prior experiences and regarded by companies as externally contracted experts.

The involvement of customers could address one of the key challenges of the innovation process, related to its initial step, described as the "fuzzy front end", which precedes the actual new product development and entails a relatively chaotic quest for new ideas and concepts (Koen et al., 2002, pp. 5-6). Throughout the fuzzy front end efforts, a company would aim to identify an opportunity, understood as an existing gap between the current status and the potential future, with a view to solve a problem or address a difficulty by the subsequent development of a new product (Koen et al., 2002, p. 7). Early involvement of customers in the generation of ideas for new products as part of the fuzzy frontend stage could reduce uncertainty and contribute to the future commercial success of innovations (Zhang \& Doll, 2001, p. 104). Such involvement of consumers-co-creators remains relatively rare in the industry, as companies tend to generate new product concepts internally by trial and error or anticipation of possible user requirements (Phillips et al., 1999, pp. 292-294; Kurkkio, 2011, pp. 262-263). Not surprisingly, the early involvement of external stakeholders allows organizations to understand the available options and expected outcomes (Schuijff \& Dijkstra, 2019, p. 535). The co-creation reflects the principles of socially responsible design, which take into account the needs of potential users while ensuring cultural appropriateness, affordability, usability and avoidance of user dependence (Melles et al., 2011, p. 149). The collective dynamics of the co-creation processes resemble the concept of social labs, which involve social experiments carried out in a practical context with a group of stakeholders (Timmermans et al., 2020, p. 412).

Co-production can be interpreted as an essential form of social innovations (Evers \& Ewert, 2021, p. 133). Despite the obvious economic and ethical benefits of involving users in the co-design of innovations, the actual involvement of users in genuine co-creation efforts remains limited. Instead of joint development of product concepts and project proposals, companies are more open to inviting stakeholders to evaluate expected outcomes of the already developed innovations and thus facilitate their sales (Schuijff \& Dijkstra, 2019, p. 563). Scientific publications tend to document the involvement of stakeholders other than the end users of innovations (Rowe \& Frewer, 2005, p. 257; Gemen et al., 2015; Khan et al., 2016). Examples of public engagement related to the evaluation of consequences of innovations, as well as to the identification and alleviation of possible societal concerns appear more frequent than participation in the development of new product concepts (Te Kulve \& Rip, 2011; Irwin et al., 2013; Pepo \& Matschoss, 2019, p. 123).

While considering limitations of the co-creation practices, it must be mentioned that the mere involvement of citizens is not a guarantee for their concerns being addressed by the innovators, especially as the participation could be used to argue for the legitimacy of end user consultations while disregarding the actual inputs (Pepo \& Matschoss, 2019, p. 121). There are different modalities of citizen engagement, including: communication (being informed), consultation (providing feedback and suggestions) and participation (bi-lateral exchanges) (Rowe \& Frewer, 2005, pp. 254-255). Genuine public participation calls for the stakeholders' 
representativeness, independence, becoming involved as early as possible and having actual influence over the outcomes (Rowe \& Frewer, 2000). At the same time, in the case of the involvement of stakeholders in the development of new product concepts, full transparency of the process would actually become problematic because the outcome innovations are important sources of competitive advantage for the interested company (Blok \& Lemmens, 2015, pp. 23-24), so tensions could arise between the transparency and the secrecy needed to successfully introduce new solutions.

\section{Universities and Socially Responsible Innovations}

The social responsibility of innovators gains increasing importance in government policies, targeting industry and science. Traditionally, the technology policies were primarily focused on stimulating the growth of innovative industry sectors (Mowery \& Rosenberg, 1989) and did not respond to the specific needs of potential end users. The Schumpeterian tradition of entrepreneurship and innovation research was oriented towards benefits derived by private companies from the development of technologies and market rivalry (Nelson, 1992, p. 57), but the reliance of the private sector on public sources of funding for Research \& Development enabled the governments to reshuffle the policy priorities as companies were no longer "the only actors in the innovation game" (Nelson, 1992, p. 60). In the 1990s, societal benefits became increasingly important with "mission-oriented policies" addressing specific challenges such as environmental sustainability (Freeman \& Soete, 1997, pp. 414-415). Nowadays, the state is not only expected to reduce private risks in innovation processes but also to actively shape the innovation agendas in response to the identified societal needs (Mazzucato, 2013). Companies adjust to these imperatives by strengthening their responsiveness to the needs of specific groups of the society, including niche users and their value systems (Stilgoe et al., 2013, p. 1573).

The development and implementation of inclusive innovations or "pro-poor innovations" address the requirements of many citizens of the developing countries described as "the bottom of the pyramid" and ideally, is enacted with their involvement (World Bank, 2010, p. 335). A similarly proactive approach, relevant also for wealthier countries, entails the pursuit of needs expressed by vulnerable groups of the society. These vulnerabilities could include among others: health or age-related deficiencies, minority status, the limited size of customer niches or low purchasing power that discourage corporate investments in product development. The latter scenario could be successfully addressed by frugal innovations-products with restricted functionalities, but still being "good-enough" and affordable (Zeschky et al., 2011). Customer vulnerabilities could actually translate into strong selling points for new products, as in the case of drugs targeting rare diseases or assistive technologies that improve the quality of life of the disabled or seniors (Bechtold et al., 2017). The promotion of socially responsible innovations could be considered "the democratic governance of intent": collective debates about purposes of 
generating and diffusing innovations (Owen et al., 2013), in an effort to address the externalities of innovations.

The principles of responsible research and innovation became embedded into the policies and funding modalities of the European Union (De Saille, 2015). They are becoming gradually imprinted upon actors of innovation systems by the national funding agencies, accreditation bodies and governmental policymakers carrying out an institutional assessment of universities and research institutes (Owen et al., 2021). In this context, the consideration for socially relevant innovations has the potential to transform the role of universities in society and helps higher education institutions change the ways of teaching and doing research, aiming to generate societally relevant outcomes of innovation processes of academia. This means a paradigm shift on multiple levels, including: individual scientists (who become more embedded into the societal context in their teaching and research), research teams (addressing specific, externally defined challenges, such as e.g. climate change, health, nutrition, ageing society, equal access to information or empowerment of citizens) and the entire institutions. This approach partly overlaps with the third mission of universities. The third mission goes beyond education and research, focusing on impacts, economic and social consequences of academic endeavours, and could include: the creation of intellectual property and spin-offs, contracts with industry and government, participation in policy-making, social and cultural life as well as public dissemination of scientific results (Laredo, 2007, pp. 447-448). Importantly, the third mission covers both revenue-generating activities (including patenting, technology transfer and spinning off companies) and non-commercial actions that offer valuable contributions to society (Montesinos et al., 2008, p. 262).

As the chapter will demonstrate, universities could become important catalysts of innovation in the private sector, developed with the involvement of customers through co-creation initiatives. Academia can leverage the specialist knowledge of scientists, good practices and participative methodologies to stimulate the dialogue between customers and companies, aiming to develop innovative, marketable products that would meet the specific demands of users and thus serve society. The academic role in stimulating co-creation initiatives is an important element of the third mission (Compagnucci \& Spigarelli, 2020, pp. 18-19). The example of the EIT Food RIS Consumer Engagement Labs project points to the unique role that higher education institutions could play in orchestrating the encounters of consumers with producers and catalyse their joint creative efforts. The co-creation process involved elderly consumers, a group usually overlooked by food and beverage companies due to the alleged, limited commercial attractiveness of the silver market. The involvement of universities made food companies more sensitive to the societal relevance of the rapidly increasing population of seniors and opened up creative opportunities, spurring a wave of food product innovations. 


\section{Experiences of EIT Food RIS Consumer Engagement Labs Project}

The EIT Food RIS Consumer Engagement Labs (further referred to as: "CEL" or "the Labs") is a project funded by the European Institute of Innovation and Technology based on the Horizon 2020 framework program of the European Union. The project consists of cooperation with consumers, who participate in creative activities involving also food companies as part of a "laboratory" dedicated to the development of new food products. The co-creation process is based on a standardized methodology, developed by the University of Warsaw and replicated throughout multiple Labs in various European countries, each focused on another food product category and involving different sets of local stakeholders.

In 2019 and 2020, the Labs were implemented in 14 countries of Central-Eastern and Southern Europe (Bulgaria, Czechia, Estonia, Greece, Hungary, Italy, Lithuania, Latvia, Poland, Portugal, Romania, Slovakia, Slovenia and Spain). Each Lab was delivered by a local consortium, including a scientific institution (a university or a research institute), companies (a food producer, a retailer and a start-up) and a non-governmental organization (altogether 46 organizations in 14 consortia). In each local consortium, the role of consortium leader was assigned to the university or research institute, tasked with the organization of local Lab, delivery of co-creation workshops, recruitment and continuous contacts with the participating consumers.

A distinctive feature of the CEL project was its focus on a selected group of participants: elderly consumers, aged 65 or more. The needs of seniors are usually overlooked by food companies, despite their specific dietary and sensory requirements. In previous studies, the involvement of seniors in the co-design of new solutions induced numerous social innovations (see e.g., Pan \& Sarantou, 2019), but the food sectors did not have comparable experiences in working with older adults. Each Lab led to the development of a long list of new product ideas in a given food product category, proposed by senior consumers and discussed with the local food companies. Following the evaluation of commercialisation feasibility and sales potential, companies were selecting the most promising ideas and initiated product development projects with a view to launching the products on the market. In 2020, 4 products resulting from CEL processes were successfully introduced to the shops in Lithuania, Poland and Spain, and 11 product concepts were selected for subsequent product development and launches planned for 2021.

The first of the Labs was organized in Poland and implemented by the Poznań University of Life Sciences in October 2019. The Lab was the pilot implementation of the CEL methodology, and it involved a local food producer Folwark Wąsowo, a retailer Gminne Składy and a startup company COFACTOR. The Poznań University of Life Sciences co-operated with authors of the methodology from the University of Warsaw in its first implementation. It ensured that the participant recruitment process followed the rules of an open call, and at the same time, that the composition of the selected consumer group met the specific requirements of socio-demographic 
diversity, including gender, age groups, education levels and urban versus rural places of residence.

In the first Lab, 20 participating seniors were divided into three teams. They were assisted and guided by facilitators from the university, who were responsible for managing the group dynamics, stimulating the participants' creativity and time management. Through a series of creative team exercises, the seniors were able to develop profiles of an idealised elderly consumer (persona), discussing her or his food practices and purchasing choices, social and family circumstances, dietary requirements, specific limitations and unmet food-related needs. These exercises made participants more attentive to the specific requirements of elderly consumers and pain points, which need to be taken into consideration while proposing new products, but are often left unnoticed or might not even be obvious to the consumers themselves (latent needs).

Armed with the awareness of food-related consumer behaviours, participants embarked on a series of creative exercises, leveraging gamification techniques and offering them opportunities to come up with ideas for new products. Owing to the sequence of multiple creative steps, each team was able to amass a long list of proposed new food product ideas. The previously developed consumer profiles served as important points of reference, helping teams identify the most suitable ideas and further develop them and then presenting them as specific product concepts to the food companies. The companies were able to listen to the outcomes of creative processes run in parallel by each of the three teams, comparing the lists of new product concepts and engaging in the subsequent dialogue with each team. The Labs process culminated with the companies selecting their preferred new product concept and refining it, taking into account specialist knowledge of food technologies and feasible technical options to achieve the product characteristics and benefits proposed by consumers. Participants of the Labs (both consumers and companies) also had opportunities to gain insights into the shopping, consumption and food preparation practices of senior consumers. The Labs methodology enticed engagement of the participating consumers and their psychological attachment. Apart from the creativity-enhancing tasks, it also ensured down-to-earth aspects such as ergonomic and safe working conditions, considerations for attention spans and dietary requirements of workshop participants.

The Labs organizers put a special emphasis on ensuring that consumers participating in the Labs could inspire food companies by their unorthodox thinking about food product portfolio development. Importantly, the consumers were also experiencing psychological and social benefits, feeling needed and useful, empowered, self-confident and successfully working with a team of new acquaintances. The creative processes involved feedback and interactions between consumers and food producers, in the form of a constructive and informative dialogue.

The proposals for new food products, put forward by consumers, were inspired by culinary traditions and desires to recreate favourite flavours with new ingredients, rendering the known and liked products more suitable for the diets of senior citizens. The dialogue with consumers made food companies more attentive to the specific needs of silver market participants. The consumers provided suggestions regarding 
flavours, ingredients and the packaging. They also managed to discover unexpected combinations and product formulas, which were subsequently refined by product development specialists for the food companies.

The product resulting from the co-creation processes carried out in Poland was a healthy beetroot salad enriched with collagen, fresh turmeric and ginger. The product leveraged beetroot as a popular ingredient of vegetable side-dishes in Poland, embedded in the local culinary tradition. Owing to the creative dynamics and inputs from consumers and companies, the product formulation included bioactive ingredients (turmeric and ginger), as well as collagen, known for healthenhancing properties, in particular: the potential to strengthen the connective tissues. In a parallel co-creation process in Lithuania, which yielded 9 proposals for new products, the local food company introduced to the market a senior-focused variation of granola, made from buckwheat. Its ingredients were processed in a way that made them crunchy but at the same time safe for the teeth, unlike the standard granola, based on baked cereals. Other interesting creative results were generated altogether in 14 countries where the CEL co-creation processes were implemented, yielding over 120 new product proposals and allowing the local companies to better understand the needs of elderly consumers, gain deeper insights into specific preferences and develop new products that meet the expectations of this important target group.

The role of co-creators became an important source of empowerment for consumers. The Labs participants were able to prove their leadership and teamwork skills, gaining respect from their peers and acknowledgement of companies, which provided extensive comments on the product proposals elaborated by consumer teams. The welcoming work environment was established by the local Labs organizers - universities, which facilitated the process, acting as intermediators between consumers and companies, and highlighting the important dimension of socially responsible innovations.

\section{University-Led Co-Creation Project and Socially Responsible Innovations}

The CEL methodology leveraged the model of co-creation involving consumers and producers, and the principles of responsible innovation. As Stilgoe et al. (2013) indicate, responsible innovation includes four dimensions: anticipation, reflexivity, inclusion and responsiveness. "Anticipation prompts researchers and organizations to ask 'what if. ..?' questions [...], to consider contingency, what is known, what is likely, what is plausible and what is possible" (Stilgoe et al., 2013, p. 1570). Reflexivity operates on both individual (personal) and institutional (systemic) levels. As authors point out, "reflexivity, at the level of institutional practice, means holding a mirror up to one's own activities, commitments and assumptions, being aware of the limits of knowledge and being mindful that a particular framing of an issue may not be universally held" (Stilgoe et al., 2013, p. 1571). On the systemic level, it 
creates "the reflexive capacity within the practice of science and innovation" by the variety of actors of science governance (Stilgoe et al., 2013, p. 1571). Inclusion materialises itself in participatory practices widening the public dialogue by involving "new voices in the governance of science and innovation as part of a search for legitimacy", including wide public, small groups considered to be "mini-publics" (Goodin \& Dryzek, 2006), as well as processes built on the multi-stakeholder partnership and other "hybrid mechanisms that attempt to diversify the inputs to and delivery of governance" (Stilgoe et al., 2013, p. 1571). While discussing the responsiveness, Stilgoe et al. (2013) refer to the double meaning of the word "respond", which could stand for "reacting" or "answering", addressing the emergence of knowledge, perspectives, norms and opinions (Stilgoe et al., 2013, p. 1572). Responsiveness also comprises "adjusting courses of action while recognising the insufficiency of knowledge and control" (Stilgoe et al., 2013, p. 1572).

Co-creation sessions enabled the inclusion of elderly consumers in the processes of proposing concepts of new food products that would address their distinctive needs and preferences. The Labs were based on the assumption that consumer engagement in the co-creation process results from direct and personal contacts with representatives of companies, and it could become crucial for developing innovative solutions for this consumer segment. Elderly consumers tend to be overlooked by marketing, sales and research and development departments of food sector companies, and their needs are marginalised. Universities implementing the Labs were able to bring together consumers and producers, creating a space for dialogue, exchange of views and joint creative efforts, overcoming the traditional commercial barriers that were discouraging corporate representatives from direct cooperation with seniors. For elderly consumers, the opportunity to unleash their creative potential and interact with food producers and scientists became also an important source of personal empowerment and self-esteem improvement. This aspect could further be interpreted through the lenses of intensity, openness and quality (Stilgoe et al., 2013, p. 1572), taking into account the depth of consumer interactions, the diversity of participants and the insightfulness of results.

Another important aspect of CEL was the inclusion of new voices in product development efforts, in this case: the voices of seniors. Product concepts developed in the Labs were targeting the food-related needs expressed by senior consumers participating in the process. The specific requirements and demands of seniors proved difficult to anticipate by scientists or corporate marketers and encompassed numerous surprises, related e.g. to childhood remembrances, nostalgia-inspired food, craving for ancient legumes that are no longer popular, or preferences for foods that do not meet a senior's dietary restrictions but which could potentially be re-engineered in a healthier and more suitable manner by replacing selected ingredients while preserving their core sensory aspects. The creative processes yielded impressive, novel results and offered various sources of inspiration for the participant companies. These insights were enabled by the facilitative role of universities, promoting the dialogue and implementing the Labs methodology, which was 
intended to broaden the creative horizons of consumers and open up the spectrum of product development opportunities.

The Labs enabled companies to respond to important societal challenges of the ageing society. This responsiveness to the growing importance of the silver consumers and their previously unmet needs could be interpreted as an example of the socially responsible strategy of food sector participants, triggered by the facilitative actions of the local university. Corporate specialists did not possess the relevant knowledge or sensitivity to consider the specific circumstances of elderly consumers, and derived tangible benefits from working with the universities as "interpreters". Consumer behaviours of seniors differ from those of younger age groups, with more conservative approaches, tendencies to avoid previously unknown foods, health-related dietary restrictions (e.g. need to eliminate certain ingredients), challenges of oral comfort (resulting i.a. in avoidance of hard or sticky foods), the chemosensory decline (resulting in less intensive experiences of flavours and smells), or lower household budgets, particularly in one-person households. Seniors are a particularly vulnerable consumer group so they could significantly benefit from food product innovations.

\section{Conclusions}

The chapter discussed how universities may facilitate co-creation processes and contribute towards the socially responsible innovations with consumers and producers. The case study of an international food co-creation project demonstrated novel dimensions of the universities' third mission, which goes beyond the mere commercialization of knowledge but rather paves way for using it for the benefits of the community and the society. This approach is encapsulated in the concept of responsible research and innovation, which combines knowledge creation with economic and social developments. Table 9.1 outlines key outcomes of the project, demonstrating specific benefits achieved by the participating companies and consumers. It clearly outlines the extent of societal contributions of universities that orchestrated this co-creation process.

HEIs have the potential to focus the attention of private and public sector stakeholders on important societal challenges. Furthermore, they also may transfer knowledge and know-how on responsible new product development processes, stimulating the social responsibility of their partner companies. HEIs act here as "interpreters" transferring their sensitivity towards societal issues onto innovation processes. The EIT Food RIS Consumer Engagement Labs project offered a comprehensive example of how the HEIs' third mission could be implemented. It was carried out in 14 European countries and established a platform for discussing the food-related needs of senior consumers, generating new product ideas and facilitating their commercialization. The co-creation methodology employed in the Labs process and follow-up activities related to new product development leveraged the model of responsible research and innovation, with respect to the dimensions of 
Table 9.1 Summary of the outcomes of the university-driven co-creation process, coordinated by universities in the EIT Food RIS Consumer Engagement Labs project

\begin{tabular}{|c|c|c|}
\hline $\begin{array}{l}\text { Step of the co-creation } \\
\text { process }\end{array}$ & Benefits for companies & Benefits for consumers \\
\hline \multirow[t]{2}{*}{$\begin{array}{l}\text { 1. Exercises aimed at under- } \\
\text { standing consumer needs } \\
\text { (development of consumer } \\
\text { personas) }\end{array}$} & $\begin{array}{l}\text { Identification of specific food- } \\
\text { related requirements, pain } \\
\text { points and latent needs of older } \\
\text { adults }\end{array}$ & $\begin{array}{l}\text { Developing the awareness of } \\
\text { older consumer food-related } \\
\text { behaviours }\end{array}$ \\
\hline & $\begin{array}{l}\text { Gathering consumers' insights } \\
\text { into older adults' food-related } \\
\text { behaviours }\end{array}$ & $\begin{array}{l}\text { Self-reflection over personal } \\
\text { food-related behaviours }\end{array}$ \\
\hline \multirow[t]{2}{*}{$\begin{array}{l}\text { 2. Creative tasks (generation } \\
\text { of new food product ideas) }\end{array}$} & $\begin{array}{l}\text { Identification of non-obvious } \\
\text { product concepts opening } \\
\text { companies to unorthodox } \\
\text { solutions }\end{array}$ & $\begin{array}{l}\text { Discovering unexpected com- } \\
\text { binations and product formulas }\end{array}$ \\
\hline & $\begin{array}{l}\text { Access to the broad set of } \\
\text { consistent product concepts } \\
\text { proposed by consumers }\end{array}$ & $\begin{array}{l}\text { Consideration of particular } \\
\text { features of products available } \\
\text { in shops and their importance } \\
\text { for the consumers }\end{array}$ \\
\hline \multirow{2}{*}{$\begin{array}{l}\text { 3. Discussion of the most } \\
\text { promising product ideas } \\
\text { between consumers and } \\
\text { companies }\end{array}$} & $\begin{array}{l}\text { Provision of product concepts } \\
\text { based on well-justified con- } \\
\text { sumer needs }\end{array}$ & Recognition from companies \\
\hline & $\begin{array}{l}\text { Opportunity to discuss the } \\
\text { assumptions, limitations of } \\
\text { concepts and receive feedback } \\
\text { from consumers on the } \\
\text { recommended refinements of } \\
\text { the product concepts }\end{array}$ & $\begin{array}{l}\text { Engaging in a dialogue with } \\
\text { companies, in which con- } \\
\text { sumers share their insights, } \\
\text { knowledge and experiences }\end{array}$ \\
\hline $\begin{array}{l}\text { 4. Commercialisation plan- } \\
\text { ning by companies }\end{array}$ & $\begin{array}{l}\text { Enhancing the product portfo- } \\
\text { lio by introducing products } \\
\text { responding to the needs of } \\
\text { older consumers }\end{array}$ & $\begin{array}{l}\text { New products that meet the } \\
\text { expectations of older con- } \\
\text { sumers available in shops }\end{array}$ \\
\hline $\begin{array}{l}\text { 5. Follow-up activities (incl. } \\
\text { Interviews with consumers) }\end{array}$ & $\begin{array}{l}\text { Gathering feedback from the } \\
\text { participants of the process } \\
\text { regarding the resulting prod- } \\
\text { ucts and consequences of the } \\
\text { process }\end{array}$ & $\begin{array}{l}\text { Receiving information about } \\
\text { the tangible results of the } \\
\text { co-creation (products available } \\
\text { in shops) }\end{array}$ \\
\hline \multirow[t]{3}{*}{$\begin{array}{l}\text { Summing up the co-creation } \\
\text { process }\end{array}$} & $\begin{array}{l}\text { Engagement in a face-to-face } \\
\text { dialogue with consumers }\end{array}$ & $\begin{array}{l}\text { Empowerment through the } \\
\text { successful completion of tasks } \\
\text { and integration with other team } \\
\text { members }\end{array}$ \\
\hline & $\begin{array}{l}\text { Better understanding of the } \\
\text { needs of older consumers }\end{array}$ & $\begin{array}{l}\text { Enhancement of leadership } \\
\text { and social skills }\end{array}$ \\
\hline & $\begin{array}{l}\text { Reinforcing the companies } \\
\text { position in the silver market }\end{array}$ & $\begin{array}{l}\text { Recognition by peers and } \\
\text { opportunities for peer-to-peer } \\
\text { learning }\end{array}$ \\
\hline
\end{tabular}

Source: Own elaboration 
anticipation, reflexivity, inclusion and responsiveness. It was achieved by responding to the societal challenges of the ageing society (responsiveness) and taking into account the demographic changes in the near future (anticipation), as well as by implementing the co-creation methodology based on a careful analysis of the positionality of stakeholders engaged in the activity (reflexivity) and aimed at the involvement of elderly consumers in the core activities of the project (inclusion).

Acknowledgement The chapter describes selected results of the EIT Food RIS Consumer Engagement Labs, a project that has received funding from the European Institute of Innovation and Technology (EIT), a body of the European Union, under the Horizon 2020 and Horizon Europe, the EU Framework Programmes for Research and Innovation.

\section{References}

Aversano, N., Carlo, F. D., Sannino, G., Polcini, P. T., \& Lombardi, R. (2020). Corporate social responsibility, stakeholder engagement, and universities: New evidence from the Italian scenario. Corporate Social Responsibility and Environmental Management, 27(4), 1892-1899. https://doi.org/10.1002/csr.1934

Bechtold, U., Capari, L., \& Gudowsky, N. (2017). Futures of ageing and technology-Comparing different actors' prospective views. Journal of Responsible Innovation, 4(2), 157-176. https:// doi.org/10.1080/23299460.2017.1360721

Berkun, S. (2007). The myths of innovation. O'Reilly.

Bijker, W. E., Hughes, T. P., \& Pinch, T. (1989). The social construction of technological systems. New directions in the sociology and history of technology. The MIT Press.

Blok, V., \& Lemmens, P. (2015). The emerging concept of responsible innovation. Three reasons why it is questionable and calls for a radical transformation of the concept of innovation. In B.-J. Koops, I. Oosterlaken, H. Romijn, T. Swierstra, \& M. J. Van Den Hoven (Eds.), Responsible innovation 2: Concepts, approaches, and applications (pp. 19-35). Springer. https://doi.org/10. 1007/978-3-319-17308-5_2

Buffel, T., Skyrme, J., \& Phillipson, C. (2017). Connecting research with social responsibility: Developing 'age-friendly' communities in Manchester, UK. In D. T. L. Shek \& R. M. Hollister (Eds.), University social responsibility and quality of life: A global survey of concepts and experiences (pp. 99-120). Springer. https://doi.org/10.1007/978-981-10-3877-8_7

Cajaiba-Santana, G. (2014). Social innovation: Moving the field forward. A conceptual framework. Technological Forecasting and Social Change, 82, 42-51. https://doi.org/10.1016/j.techfore. 2013.05.008

Carrier, M., \& Gartzlaff, M. (2020). Responsible research and innovation: Hopes and fears in the scientific community in Europe. Journal of Responsible Innovation, 7(2), 149-169. https://doi. org/10.1080/23299460.2019.1692571

Compagnucci, L., \& Spigarelli, F. (2020). The third Mission of the university: A systematic literature review on potentials and constraints. Technological Forecasting and Social Change, 161, 120284. https://doi.org/10.1016/j.techfore.2020.120284

De Saille, S. (2015). Innovating innovation policy: The emergence of 'responsible research and innovation'. Journal of Responsible Innovation, 2(2), 152-168. https://doi.org/10.1080/ 23299460.2015.1045280

Etzkowitz, H. (1983). Entrepreneurial scientists and entrepreneurial universities in American academic science. Minerva, 21(2), 198-233. https://doi.org/10.1007/BF01097964

Etzkowitz, H. (2013). Anatomy of the entrepreneurial university. Social Science Information, 52(3), 486-511. https://doi.org/10.1177/0539018413485832 
Etzkowitz, H., Webster, A., \& Healey, P. (1998). Capitalizing knowledge: New intersections of industry and academia. SUNY Press.

Evers, A., \& Ewert, B. (2021). Understanding co-production as a social innovation. In E. Loeffler \& T. Bovaird (Eds.), The Palgrave handbook of co-production of public services and outcomes (pp. 133-153). Palgrave Macmillan. https://doi.org/10.1007/978-3-030-53705-0

Flores, M., Boer, C., Huber, C., \& pluess, A., Schoch, R., \& Pouly, M. (2007). The role of universities developing new collaborative environments: Analysing the virtuelle fabrik, swiss microtech and the tenet group. Establishing the Foundation of Collaborative Networks, 243. https://doi.org/10.1007/978-0-387-73798-0_13

Freeman, C., \& Soete, L. (1997). The economics of industrial innovation (3rd ed.). PINTER. https:// doi.org/10.4324/9780203064474

Fukugawa, N. (2017). University spillover before the national innovation system reform in Japan. International Journal of Technology Management, 73(4), 206-234. https://doi.org/10.1504/ IJTM.2017.083079

Gemen, R., Breda, J., Coutinho, D., Fernández Celemín, L., Khan, S., Kugelberg, S., et al. (2015). Stakeholder engagement in food and health innovation research programming - Key learnings and policy recommendations from the INPROFOOD project. Nutrition Bulletin, 40(1), 54-65. https://doi.org/10.1007/s11948-019-00167-3

Gimenez, A. M. N., \& Bonacelli, M. B. M. (2019). A terminological study about university-society relations: Third mission, socioeconomic surroundings and the evolution of the role of academia. SocArXiv. https://doi.org/10.31235/osf.io/36hkb

Goodin, R., \& Dryzek, J. (2006). Deliberative impacts: The macro-political uptake of mini-publics. Politics and Society, 34, 219-244. https://doi.org/10.1177/0032329206288152

Inigo, E. A., \& Blok, V. (2019). Strengthening the socio-ethical foundations of the circular economy: Lessons from responsible research and innovation. Journal of Cleaner Production, 233, 280-291. https://doi.org/10.1016/j.jclepro.2019.06.053

Irwin, A., Jensen, T. E., \& Jones, K. E. (2013). The good, the bad and the perfect: Criticizing engagement practice. Social Studies of Science, 43(1), 118-135. https://doi.org/10.1177/ 0306312712462461

Jarmai, K., \& Vogel-Pöschl, H. (2020). Meaningful collaboration for responsible innovation. Journal of Responsible Innovation, 7(1), 138-143. https://doi.org/10.1080/23299460.2019. 1633227

Jessop, B., Moulaert, F., Hulgard, L., \& Hamdouch, A. (2013). Social innovation research: A new stage in innovation analysis? In F. Moulaert, D. MacCallum, A. Mehmood, \& A. Hamdouch (Eds.), The international handbook on social innovation: Collective action, social learning and transdisciplinary research (pp. 110-130). Edward Elgar.

Kattel, R., \& Mazzucato, M. (2018). Mission-oriented innovation policy and dynamic capabilities in the public sector. Industrial and Corporate Change, 27(5), 787-801. https://doi.org/10.1093/ icc/dty032

Khan, S. S., Timotijevic, L., Newton, R., Coutinho, D., Llerena, J. L., Ortega, S., et al. (2016). The framing of innovation among European research funding actors: Assessing the potential for 'responsible research and innovation' in the food and health domain. Food Policy, 62, 78-87. https://doi.org/10.1016/j.foodpol.2016.04.004

Koen, P. A., Ajamian, G. M., Boyce, S., Clamen, A., Fisher, E., Fountoulakis, S., et al. (2002). Fuzzy front end: Effective methods, tools, and techniques. In P. Belliveau, A. Griffin, \& S. Somermeyer (Eds.), The PDMA Toolbook for new product development (pp. 5-35). Wiley.

Kurkkio, M. (2011). Managing the fuzzy front-end: Insights from process firms. European Journal of Innovation Management, 14(2), 252-269. https://doi.org/10.1108/14601061111124911

Laloux, F. (2014). Reinventing organizations. A guide to creating organizations inspired by the next stage of human consciousness. Nelson Parker.

Laredo, P. (2007). Revisiting the third mission of universities: Toward a renewed categorization of university activities? Higher Education Policy, 20(4), 441-456. 
Leydesdorff, L., \& Etzkowitz, H. (1998). The triple helix as a model for innovation studies. Science and Public Policy, 25(3), 195-203. https://doi.org/10.1093/spp/25.3.195

Lund, R. (2020). The social organisation of boasting in the neoliberal university. Gender and Education, 32(4), 466-485. https://doi.org/10.1080/09540253.2018.1482412

Mazzucato, M. (2013). The entrepreneurial state. Debunking public vs. private sector myths. Anthem Press.

Meadows, L. (2002). Lead user research and trend mapping. In P. Belliveau, A. Griffin, \& S. Somermeyer (Eds.), The PDMA Toolbook for new product development (pp. 243-266). John Wiley \& Sons.

Melles, G., de Vere, I., \& Misic, V. (2011). Socially responsible design: Thinking beyond the triple bottom line to socially responsive and sustainable product design. CoDesign, 7(3-4), 143-154. https://doi.org/10.1080/15710882.2011.630473

Miller, C., \& Swaddling, D. C. (2002). Focusing NPD research on customer-perceived value. In P. Belliveau, A. Griffin, \& S. Somermeyer (Eds.), The PDMA Toolbook for new product development (pp. 87-114). John Wiley \& Sons.

Montesinos, P., Carot, J. M., Martinez, J.-M., \& Mora, F. (2008). Third mission ranking for world class universities: Beyond teaching and research. Higher Education in Europe, 33(2-3), 259-271. https://doi.org/10.1080/03797720802254072

Mowery, D. C., \& Rosenberg, N. (1989). Technology and the pursuit of economic growth. Cambridge University Press. https://doi.org/10.1017/CBO9780511664441

Naisbitt, J. (2001). High tech high touch. Technology and our accelerated search for meaning. Nicholas Brealey Publishing.

Nelson, R. (1992). What is "commercial" and what is "public" about technology, and what should be? In N. Rosenberg, R. Landau, \& D. C. Mowery (Eds.), Technology and the wealth of nations (pp. 57-71). Stanford University Press.

Nielsen, M. V. (2016). The concept of responsiveness in the governance of research and innovation. Science and Public Policy, 43(6), 831-839. https://doi.org/10.1093/scipol/scv078

Ocean, M., Calvano, L., \& McGorry, M. (2020). Bridging the gap between the community and the ivory tower: A case study of university-community college partnership models. In E. Sengupta, P. Blessinger, \& C. Mahoney (Eds.), University-community partnerships for promoting social responsibility in higher education (Vol. 23, pp. 201-213). Emerald Publishing Limited. https:// doi.org/10.1108/S2055-364120200000023014

OECD/Eurostat. (2018). Oslo manual 2018: Guidelines for collecting, reporting and using data on innovation (4th ed.). OECD Publishing.

Owen, R., Macnaghten, P., \& Stilgoe, J. (2012). Responsible research and innovation: From science in society to science for society, with society. Science and Public Policy, 39(6), 751-760. https://doi.org/10.1093/scipol/scs093

Owen, R., Pansera, M., Macnaghten, P., \& Randles, S. (2021). Organisational institutionalisation of responsible innovation. Research Policy, 50(1), 104132. https://doi.org/10.1016/j.respol.2020. 104132

Owen, R., Stilgoe, J., Macnaghten, P., Gorman, M., Fisher, E., \& Guston, D. (2013). A framework for responsible innovation. In R. Owen, J. Bessant, \& M. Heintz (Eds.), Responsible innovation. Managing the responsible emergence of science and innovation in society (pp. 27-50). Wiley. https://doi.org/10.1002/9781118551424.ch2

Pan, S., \& Sarantou, M. (2019). Ageing communities as co-designers of social innovation. China Journal of Social Work, 12(3), 273-286. https://doi.org/10.1080/17525098.2019.1700342

Papadimitriou, A. (2020). Beyond rhetoric: Reinventing the public mission of higher education. Tertiary Education and Management, 26(1), 1-4. https://doi.org/10.1007/s11233-019-09046-9

Pepo, P., \& Matschoss, K. (2019). Considering expert takeovers in citizen involvement processes. Journal of Responsible Innovation, 6(2), 119-142. https://doi.org/10.1080/23299460.2019. 1568145

Perez, C. (2002). Technological revolutions and financial capital. The dynamics of bubbles and golden ages. Edward Elgar. https://doi.org/10.1017/S002205070348193X 
Phillips, R., Neailey, K., \& Broughton, T. (1999). A comparative study of six stage-gate approaches to product development. Integrated Manufacturing Systems, 10(5), 289-297.

Potts, J. (2019). Innovation commons. The origin of economic growth. Oxford University Press. https://doi.org/10.1093/oso/9780190937492.001.0001

Prahalad, C. K., \& Ramaswamy, V. (2006). The future of competition. Co-creating unique value with customers. Portfolio. https://doi.org/10.5465/ame.2004.13835520

Ribeiro, B., Bengtsson, L., Benneworth, P., Bührer, S., Castro-Martínez, E., Hansen, M., Jarmai, K., Lindner, R., Olmos-Peñuela, J., Ott, C., \& Shapira, P. (2018). Introducing the dilemma of societal alignment for inclusive and responsible research and innovation. Journal of Responsible Innovation, 5(3), 316-331. https://doi.org/10.1080/23299460.2018.1495033

Rogers, E. M. (1995). Diffusion of innovations (4th ed.). The Free Press.

Rowe, G., \& Frewer, L. J. (2000). Public participation methods: A framework for evaluation. Science, Technology \& Human Values, 25(1), 3-29. https://doi.org/10.1177/ 016224390002500101

Rowe, G., \& Frewer, L. J. (2005). A typology of public engagement mechanisms. Science, Technology \& Human Values, 30(2), 251-290. https://doi.org/10.1177/0162243904271724

Rubens, A., Spigarelli, F., Cavicchi, A., \& Rinaldi, C. (2017). Universities' third mission and the entrepreneurial university and the challenges they bring to higher education institutions. Journal of Enterprising Communities: People and Places in the Global Economy. https://doi. org/10.1108/JEC-01-2017-0006.

Sánchez-Barrioluengo, M., \& Benneworth, P. (2019). Is the entrepreneurial university also regionally engaged? Analysing the influence of university's structural configuration on third mission performance. Technological Forecasting and Social Change, 141, 206-218. https://doi.org/10. 1016/j.techfore.2018.10.017

Schuijff, M., \& Dijkstra, A. M. (2019). Practices of responsible research and innovation: A review. Science and Engineering Ethics, 26, 533-574. https://doi.org/10.1007/s11948-019-00167-3

Secundo, G., Elena Perez, S., Martinaitis, Ž., \& Leitner, K. H. (2017). An intellectual capital framework to measure universities' third mission activities. Technological Forecasting and Social Change, 123, 229-239. https://doi.org/10.1016/j.techfore.2016.12.013

Stilgoe, J., Owen, R., \& Macnaghten, P. (2013). Developing a framework for responsible innovation. Research Policy, 42, 1568-1580. https://doi.org/10.1016/j.respol.2013.05.008

Tapscott, D., \& Williams, A. D. (2006). Wikinomics. How mass collaboration changes everything. Portfolio. https://doi.org/10.1111/j.1460-2466.2008.00391_5.x

Taylor, A. (2017). Perspectives on the university as a business: The corporate management structure, neoliberalism and higher education. Journal for Critical Education Policy Studies, 15(1), 108-135.

Te Kulve, H., \& Rip, A. (2011). Constructing productive engagement: Pre-engagement tools for emerging technologies. Science and Engineering Ethics, 17, 699-714. https://doi.org/10.1007/ s11948-011-9304-0

Timmermans, J., Blok, V., Braun, R., Wesselink, R., \& Nielsen, R. O. (2020). Social labs as an inclusive methodology to implement and study social change: The case of responsible research and innovation. Journal of Responsible Innovation, 7(3), 410-426. https://doi.org/10.1080/ 23299460.2020 .1787751

Torres, C. A., \& Schugurensky, D. (2002). The political economy of higher education in the era of neoliberal globalization: Latin America in comparative perspective. Higher Education, 43(4), 429-455. https://doi.org/10.1023/A:1015292413037

Trencher, G., Yarime, M., McCormick, K. B., Doll, C. N. H., \& Kraines, S. B. (2014). Beyond the third mission: Exploring the emerging university function of co-creation for sustainability. Science and Public Policy, 41(2), 151-179. https://doi.org/10.1093/scipol/sct044 
Wanzenböck, I., Wesseling, J. H., Frenken, K., Hekkert, M. P., \& Weber, K. M. (2020). A framework for mission-oriented innovation policy: Alternative pathways through the problemsolution space. Science and Public Policy, 47(4), 474-489. https://doi.org/10.1093/scipol/ scaa027

World Bank. (2010). Innovation policy. A guide for developing countries. The World Bank.

Zeschky, M., Widenmayer, B., \& Gassmann, O. (2011). Frugal innovation in emerging markets. Research-Technology Management, 54(4), 38-45. https://doi.org/10.5437/08956308X5404007

Zhang, Q., \& Doll, W. J. (2001). The fuzzy front end and success of new product development: A causal model. European Journal of Innovation Management, 4(2), 95-112. https://doi.org/10. $1108 / 14601060110390602$

Krzysztof Klincewicz, PhD is Professor at the Faculty of Management, University of Warsaw. He specializes in the management of technology and innovation, with a particular interest in strategies of technology firms and R\&D management. Prior to joining the University, he had worked in hightech industry in Poland, Finland, the UK, and at the Tokyo Institute of Technology. Expert in analyzing innovation policies of EU member states in the Research and Innovation Observatory of the European Commission. Former member of the UN Technology Executive Committee and the management board of EIT Food. Coordinator of the EIT Food RIS Consumer Engagement Labs project.

Magdalena Zatorska is social researcher and ethnographer. Research fellow at the EIT Food RIS Consumer Engagement Labs project, Faculty of Management, University of Warsaw; PhD student at the Institute of Ethnology and Cultural Anthropology, University of Warsaw. Her research interests include food studies, anthropology of heritage and identity, methodology of social research, and ethical questions in social research. Her $\mathrm{PhD}$ focuses on the socio-cultural aspects of the development of Hasidic pilgrimage centres in Poland and Ukraine, with a particular focus on local heritage policies.

Anna Wielicka-Regulska, PhD is Assistant Professor of Behavioural Economics at Poznań University of Life Sciences. Her work focuses on choice theory, participatory approach in policy making and a transformation of food systems. She holds a PhD diploma from the University of Warsaw. She is an active member of international research initiatives: Multidisciplinary innovation for social change (COST Action), the EIT Food RIS Consumer Engagement Labs, Who cares in Europe? (COST Action), Enhancing the capacity of universities to initiate and to participate in clusters development on innovation and sustainability principles (UniClaD). She is also interested in neurophysiological measures to guide the understanding of the human decision-making process with application to the new product development and policy.

Open Access This chapter is licensed under the terms of the Creative Commons Attribution 4.0 International License (http://creativecommons.org/licenses/by/4.0/), which permits use, sharing, adaptation, distribution and reproduction in any medium or format, as long as you give appropriate credit to the original author(s) and the source, provide a link to the Creative Commons license and indicate if changes were made.

The images or other third party material in this chapter are included in the chapter's Creative Commons license, unless indicated otherwise in a credit line to the material. If material is not included in the chapter's Creative Commons license and your intended use is not permitted by statutory regulation or exceeds the permitted use, you will need to obtain permission directly from the copyright holder.

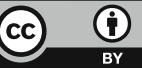

